\title{
Secondary triatomine species in dwellings and other nearby structures in municipalities under epidemiological surveillance in the state of Paraná, Brazil
}

\author{
Ana Lucia Falavigna Guilherme, ${ }^{1}$ Gilberto Cezar Pavanelli, ${ }^{1}$ \\ Sandra Vieira Silva, ${ }^{3}$ Arnaldo Lima Costa, ${ }^{2}$ \\ and Silvana Marques de Araújo 3
}

ABSTRACT Objective. Since data are scarce regarding secondary triatomine species in the Brazilian state of Paraná, this study investigated infestations in inhabited and abandoned houses and in various other nearby structures in rural areas of that state.

Methods. Triatomines were manually captured in inhabited and uninhabited houses and other nearby structures in nine areas (eight municipalities and one district) of Paraná from June 1996 to February 2000. Testing for Trypanosoma cruzi infection was performed, as were also precipitin tests to determine the triatomines' food sources.

Results. While Triatoma infestans was not found in any of the nine areas of Paraná that were studied, three secondary triatomine species were detected: Triatoma sordida, Panstrongylus megistus, and Rhodnius neglectus. T. sordida was the most common species found, comprising 575 of the 658 triatomines captured (87.4\%). The second-most common was P. megistus, with 82 specimens (12.5\%). Of the various categories of structures investigated, uninhabited houses was the most frequently infested category (19/62, or 30.6\%), followed by chicken coops (24/350, or 6.9\%). The primary food source of the triatomines was the blood of birds. Nevertheless, in the municipality with the highest density of triatomines, the food sources included domestic animals and even humans. We found that $13.4 \%$ of the T. sordida and $13.5 \%$ of the P. megistus were infected with Trypanosoma cruzi.

Conclusions. These results demonstrate the need to maintain entomological surveillance measures in the studied areas. This is especially important since Brazil and other countries of Latin America have affirmed the need to interrupt the vector-borne transmission of Chagas' disease.

Key words Triatominae, Chagas' disease, Brazil, epidemiological surveillance.

In 1983 Brazil launched a general attack to control Chagas' disease in all the endemic areas of the country. Over the following years, the control activities
Continentais, Av. Colombo 5790, CEP 87020-900, Maringá, Paraná, Brasil; e-mail: alf@wnet.com.br. 2 Fundação Nacional de Saúde (FUNASA), Subdistrito de Maringá, Paraná, Brasil.

3 Universidade Estadual de Maringá, Departamento de Análises Clínicas, Maringá, Paraná, Brasil. clearly produced a decrease in vectorborne transmission, especially through the control of Triatoma infestans (Klug 1834), one of the main vectors of Trypanosoma (Schizotrypanum) cruzi (Chagas 1909) (1). With that triatomine under control, there was a need seen for an improved understanding of the risks 
presented by secondary vector species such as Triatoma brasiliensis (Neiva 1911), Panstrongylus megistus (Burmeister 1835), and Triatoma sordida (Stal 1859) (2). Originally sylvan, triatomines formed colonies in "artificial ecotopes" (for example, houses and other nearby structures such as chicken coops, barns, and pigsties) because of favorable conditions, including protection from predators and inclement weather as well as abundant, easily acquired food sources (3).

The T. cruzi parasite has an extremely diverse range of vertebrate hosts. Humans are its main domesticcycle reservoir, followed by dogs, cats, and household rodents (1). Regarding the sylvatic cycle, numerous species of terrestrial and arboreal animals have been found naturally infected with $T$. cruzi in all areas where Chagas' disease is endemic (1). While this makes the eradication of human disease difficult, it does not rule out the possibility of a significant reduction (4).

There are few reports in the literature regarding secondary triatomine species with vectorial potential in the state of Paraná, which is located in the south of Brazil. Chagas' disease occurs most frequently in the northern region of the state (5). During the 1970s a prevalence of $7.4 \%$ was found among blood bank donors (6), and a study in the 1990s found that $6.3 \%$ of residents in northwest Paraná had positive serology (7). According to Silveira and Vinhaes (2), the National Health Foundation (NHF) did not report triatomine detection in domestic environments in the state in 1995 and 1997. The NHF, which is a Brazilian Government agency responsible for public health programs, has a technical department that deals with vector-transmitted diseases. With respect to triatomines and Chagas' disease, the NHF's activities include entomological inspection, strategies to control house infestation, insecticide spraying, and health education. In spite of the results reported by Silveira and Vinhaes (2), Toledo et al. (8) found triatomines in abandoned houses and in barns and chicken coops in northwestern Paraná during the 1990s.
This study investigated the occurrence of triatomine infestations in artificial ecotopes, the percent of triatomines infected with $T$. cruzi, and the insects' food sources in rural areas of northwest Paraná that were classified as "priority II" or as "priority III" by the NHF and were thus under epidemiological surveillance (9).

\section{MATERIAL AND METHODS}

\section{Description of study area}

The sites we evaluated are located in the northwest Paraná mesoregion, situated between $52^{\circ} 20^{\prime}$ and $52^{\circ} 50^{\prime}$ west longitude and $23^{\circ} 20^{\prime}$ and $23^{\circ} 60^{\prime}$ south latitude (Figure 1). The region is part of the geomorphologic unit called the Paraná Basin Central Plateau (10), which is part of the third Paraná plateau, or the Sandstone-Basaltic Plateau. The terrain consists of low flattopped plateaus with convex slopes that reach altitudes of 250 to $600 \mathrm{~m}$.

The region's climate is classified as temperate-tropical (11). Average annual rainfall is $1700 \mathrm{~mm}$. The overall average annual temperature is $21.9{ }^{\circ} \mathrm{C}$ (12). In the winter dry season average temperatures are below $18^{\circ} \mathrm{C}$. The average yearly low is $16^{\circ} \mathrm{C}$, and the average annual high temperatures range from $26^{\circ} \mathrm{C}$ to $28^{\circ} \mathrm{C}$.

In Parana the old-growth subtropical forest was practically gone by the beginning of the twentieth century, having been destroyed by logging, coffee plantation expansion, and charcoal production. By 1980 only 5\% of the original forests were left, and by 1990 only $2.6 \%$ of the original vegetation remained, mainly in parks and conservation areas (13). The coffee-growing regions were home to large populations made up primarily of people who had immigrated to Paraná from the states of São Paulo and Minas Gerais. Later, however, problems related to markets and the climate decreased coffee production and led to an expansion in soybean cultivation (14). The economy of northwestern Paraná is now dominated by the pro- duction of agricultural crops and by cattle raising on small and mediumsized rural properties (12).

Since the 1970s there has been an intense rural exodus from the northwest region of Paraná, with dramatic population changes that have left rural areas practically unpopulated (14). Many dwellings from earlier decades that had been linked to coffee growing were demolished, and many of the remaining structures have been abandoned. The majority of the existing houses are made of wood, have ceramic tile roofs, and have electric power. Common economic activities now include raising cattle, logging of reforested lands, and cultivation of soybeans, corn, sugar cane, manioc, wheat, and grapes (12).

\section{Analyzed sites}

In our study we analyzed a total of eight municipalities and one district in the northwest of Paraná (a district is a dependency or subdivision of a municipality and has no political autonomy) (Figure 1). Of the nine sites we studied, five of them were classified by the NHF/Paraná (NHF/PR, the Paraná state division of the NHF) as "priority II," three were classified as "priority III," and one had not been classified. The municipalities of Floresta, Mandaguari, Ourizona, and Maringá were inspected, as was also the district of Floriano. These municipalities and the district were classified by the NHF/PR as priority II. The three "priority III" municipalities that were evaluated were Paiçandu, Dr. Camargo, and Marialva. The study also covered the municipality of Porto Rico, which was not included on the NHF priority list.

The technical standards of the NHF/PR (9) state that priority II sites are those where the NHF has verified the colonization of an inhabited house with vectorial species such as $T$. sordida and $P$. megistus, through active searches or reports within the preceding 3 years. This classification requires that rural "domiciliary units" (DUs) 
FIGURE 1. Map of the Brazilian state of Paraná, with highlighted areas indicating the eight municipalities and one district analyzed for triatomine presence from June 1996 through February 2000.

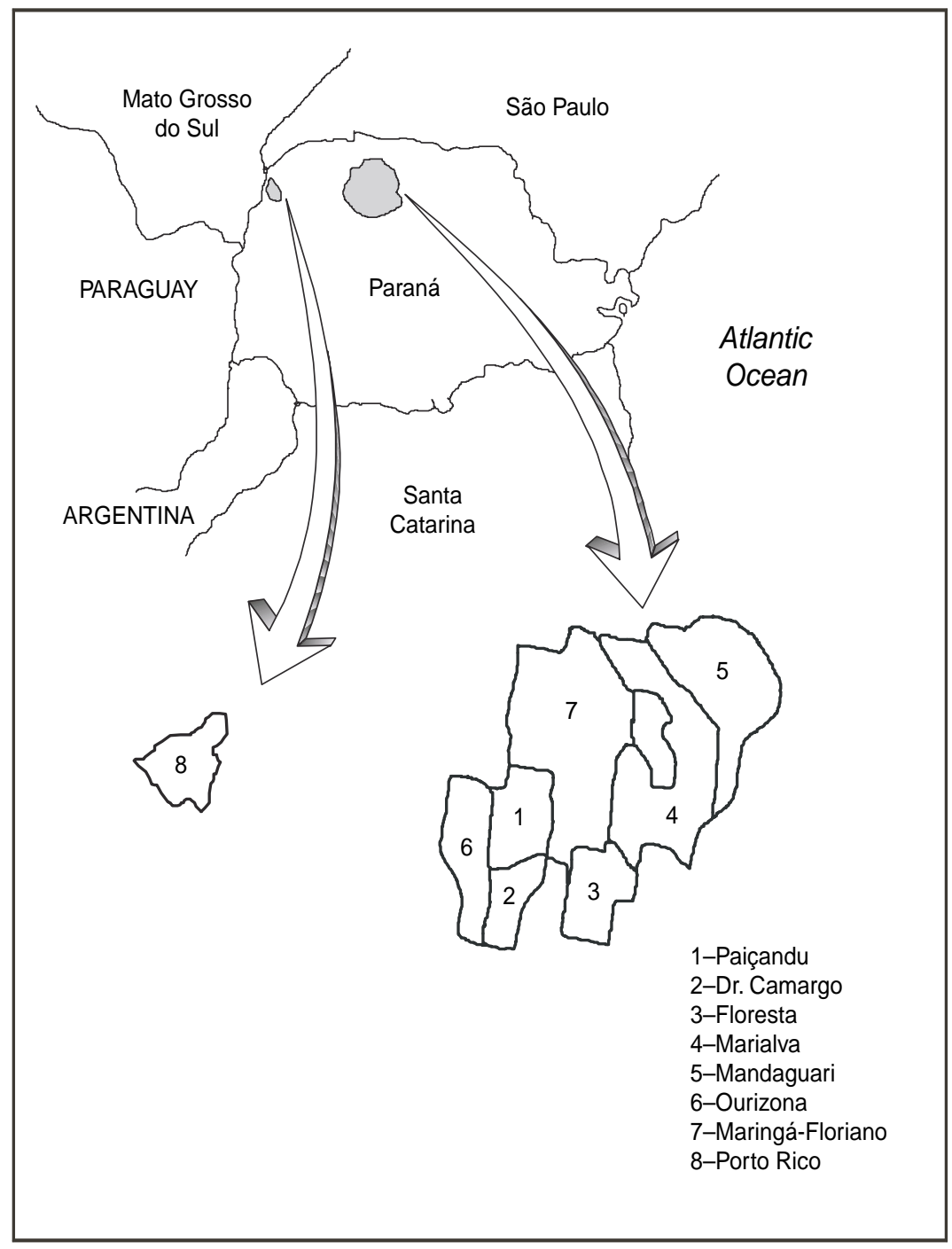

within the municipalities be surveyed every 2 years for triatomines. A DU is a dwelling with its nearby, peridomestic annexes such as a chicken coop, pigsty, or barn. Each of these dwellings or annexes is called an "ecotope" in this work. A typical DU in our study consisted of five or six individual ecotopes.

Priority III sites are those where the NHF has identified the colonization of $T$. sordida and P. megistus in peridomestic annexes in the preceding 5 years. These sites require triatomine surveys every 3 years.

In spite of these surveillance requirements, the triatomine control campaign in the northwest region of Paraná was interrupted in 1986 and restarted only in June 1996.

\section{Procedures}

Study locations were defined according to the NHF's activity timeline for entomological surveillance or were based on reports of infestation made to the NHF. Collection of triatomines and epidemiological information was made once a week by teams from the State University of Maringá and from the NHF/PR. The study was performed from June 1996 to February 2000.

\section{Epidemiological data collection instrument}

The data collection form was based on a model used by Diotaiuti et al. (15). During site visits, a form was completed for each inhabited or uninhabited rural DU. For an inhabited rural DU, data were recorded regarding the dwelling and annexes constructed in the area (chicken coops, corrals, pigsties, barns, garages, sheds, wood piles, etc.). The distance between the dwelling and annexes infested with triatomines was measured.

\section{Entomological inspection}

A team of workers from the NHF/ PR and from the State University of Maringá conducted the search for triatomines in the dwellings and annexes. Triatomines were manually captured from external and internal walls, roofs, and ceilings as well as from furniture, mattresses, and other objects within the domiciles. Similar procedures were adopted for inhabited and uninhabited houses. Locations were considered positive if nymphs and/or adults were found. Infested ecotopes were treated by the NHF with the insecticide cypermethrin (125 mg active ingredient $\left./ \mathrm{m}^{2}\right)$.

\section{T. cruzi testing}

Some of the captured triatomines were sent to the parasitology laboratory of the State University of Maringá for testing for T. cruzi. There, the triatomines were submitted to abdominal compression, and the resulting material was examined in saline solution. The stomach content was cultured in liver 
infusion tryptose medium, using the method described in Bronfen et al. (16).

\section{Triatomine food sources}

Some of the triatomines examined for $T$. cruzi infection were also tested for the triatomines' blood-meal sources, using a precipitin test (17). The abdominal material was placed on filter paper, labeled, frozen at $-20^{\circ} \mathrm{C}$, and later sent to the entomological laboratory of the Oswaldo Cruz Foundation in Rio de Janeiro, where the precipitin tests were done. The antiserums used were antibird, -dog, -cat, -goat or -cow, -human, -skunk, -horse, -pig, -rodent, -frog, and -lizard (15).

\section{Statistical analysis}

We compared the frequency of triatomine infestation in each of the artificial ecotopes using the chi-square test $\left(\chi^{2}\right)$ done with STATISTICA version 8.0 software (StatSoft, Inc., Tulsa, Oklahoma, United States of America).

\section{RESULTS}

In the eight municipalities and the one district, 520 DUs were investigated, which included 824 houses. Of these houses, 762 of them were inhabited and 62 were uninhabited (Table 1). Table 1 also lists the 12 types of ecotopes and the sample total of 2756 in- dividual ecotopes studied, of which 96 $(3.5 \%)$ were positive for triatomines. Ecotope infestation rates ranged from $1.3 \%$ for corrals and garages up to $30.6 \%$ for uninhabited houses. In decreasing order of frequency, the captured species were T. sordida, $P$. megistus, and Rhodnius neglectus (Lent 1954).

The association between ecotope and triatomine infestation was significant $\left(\chi^{2}=165.56\right.$, degrees of freedom $=$ $11, P<0.01)$. The interior of uninhabited houses was the ecotope with the highest degree of triatomine infestation in the region, followed by the category of chicken coops.

Triatomines were found inside 12 inhabited houses (Table 1), with one to four triatomine specimens (adult or

TABLE 1. Artificial ecotopes where triatomines were captured in rural areas of northwest Paraná state, Brazil, from June 1996 to February 2000

\begin{tabular}{|c|c|c|c|c|c|}
\hline \multirow{2}{*}{$\begin{array}{l}\text { Category of } \\
\text { ecotope }\end{array}$} & \multirow[b]{2}{*}{ Survey sites } & \multirow[b]{2}{*}{ Captured species } & \multirow{2}{*}{$\begin{array}{l}\text { Individual ecotopes studied } \\
\text { (No.) }\end{array}$} & \multicolumn{2}{|c|}{ Infested ecotopes } \\
\hline & & & & No. & $\%$ \\
\hline \multirow{5}{*}{$\begin{array}{l}\text { Uninhabited house } \\
\text { (interior) }\end{array}$} & Dr. Camargo & T. sordida & \multirow[t]{5}{*}{62} & \multirow[t]{5}{*}{19} & \multirow[t]{5}{*}{30.6} \\
\hline & Floriano & T. sordida & & & \\
\hline & Mandaguari & P. megistus & & & \\
\hline & Maringá & T. sordida or P. megistus & & & \\
\hline & Paiçandu & T. sordida or P. megistus & & & \\
\hline \multirow{6}{*}{$\begin{array}{l}\text { Inhabited house } \\
\text { (interior) }\end{array}$} & Paiçandu & T. sordida & \multirow[t]{6}{*}{762} & \multirow[t]{6}{*}{12} & \multirow[t]{6}{*}{1.6} \\
\hline & Floriano & T. sordida & & & \\
\hline & Mandaguari & P. megistus & & & \\
\hline & Marialva & P. megistus & & & \\
\hline & Maringá & P. megistus & & & \\
\hline & Porto Rico & R.. neglectus & & & \\
\hline \multirow[t]{5}{*}{ Chicken coop } & Paiçandu & T. sordida & \multirow[t]{5}{*}{350} & \multirow[t]{5}{*}{24} & \multirow[t]{5}{*}{6.9} \\
\hline & Dr. Camargo & T. sordida & & & \\
\hline & Floriano & T. sordida & & & \\
\hline & Floresta & T. sordida & & & \\
\hline & Marialva & T. sordida & & & \\
\hline Barn & Paiçandu & T. sordida or P. megistus & 156 & 7 & 4.5 \\
\hline \multirow[t]{4}{*}{ Lumber room } & Paiçandu & T. sordida & \multirow[t]{4}{*}{581} & \multirow[t]{4}{*}{14} & \multirow[t]{4}{*}{2.4} \\
\hline & Dr. Camargo & T. sordida & & & \\
\hline & Floriano & T. sordida & & & \\
\hline & Mandaguari & P. megistus & & & \\
\hline \multirow[t]{4}{*}{ Pigsty } & Paiçandu & T. sordida & \multirow[t]{4}{*}{223} & \multirow[t]{4}{*}{8} & \multirow[t]{4}{*}{3.6} \\
\hline & Dr. Camargo & T. sordida & & & \\
\hline & Floresta & T. sordida & & & \\
\hline & Maringá & T. sordida & & & \\
\hline \multirow[t]{2}{*}{ Garage } & Paiçandu & T. sordida & \multirow[t]{2}{*}{232} & \multirow[t]{2}{*}{3} & 1.3 \\
\hline & Dr. Camargo & T. sordida & & & \\
\hline Corral & Dr. Camargo & T. sordida & 150 & 2 & 1.3 \\
\hline Shed & Paiçandu & T. sordida & 105 & 2 & 1.9 \\
\hline & Porto Rico & P. megistus & & & \\
\hline Outdoor oven & Paiçandu & T. sordida & 47 & 1 & 2.1 \\
\hline Wood pile & Paiçandu & T. sordida & 55 & 3 & 5.5 \\
\hline & Maringá & T. sordida or P. megistus & & & \\
\hline Tile shingle pile & Dr. Camargo & T. sordida & 33 & 1 & 3.0 \\
\hline Total & & & 2756 & 96 & 3.5 \\
\hline
\end{tabular}


TABLE 2. T. cruzi infection rate in triatomine nymphs and adults captured in rural sites in northwestern Paraná state, Brazil, from June 1996 to February 2000

\begin{tabular}{|c|c|c|c|c|c|c|c|c|c|c|c|c|}
\hline \multirow[b]{3}{*}{ Survey site } & \multirow[b]{3}{*}{ Species } & & & \multicolumn{3}{|c|}{ Nymphs } & \multicolumn{3}{|c|}{ Adults } & \multicolumn{3}{|c|}{ Total } \\
\hline & & \multicolumn{2}{|c|}{ No. captured } & \multirow{2}{*}{$\frac{\text { Examined }}{(\text { No. })}$} & \multicolumn{2}{|c|}{ Infected } & \multirow{2}{*}{$\frac{\text { Examined }}{\text { (No.) }}$} & \multicolumn{2}{|c|}{ Infected } & \multirow{2}{*}{$\begin{array}{c}\text { Examined } \\
\text { (No.) }\end{array}$} & \multicolumn{2}{|c|}{ Infected } \\
\hline & & Nymphs & Adults & & No. & $\%$ & & No. & $\%$ & & No. & $\%$ \\
\hline \multirow[t]{2}{*}{ Paiçandu } & T. sordida & 268 & 80 & 119 & 11 & 14.3 & 50 & 16 & 32.0 & 169 & 33 & 19.5 \\
\hline & P. megistus & 8 & 6 & 3 & 7 & 33.3 & 2 & 0 & 0.0 & 5 & 1 & 20.0 \\
\hline Dr. Camargo & T. sordida & 77 & 20 & 31 & 0 & 0.0 & 13 & 0 & 0.0 & 44 & 0 & 0.0 \\
\hline Floriano & T. sordida & 47 & 12 & 24 & 0 & 0.0 & 9 & 0 & 0.0 & 33 & 0 & 0.0 \\
\hline \multirow[t]{2}{*}{ Marialva } & T. sordida & 25 & 25 & 1 & 0 & 0.0 & 0 & NA & NA & 1 & 0 & 0.0 \\
\hline & P. megistus & 1 & 0 & 0 & NA & NA & NA & NA & NA & 0 & NA & NA \\
\hline Ourizona & NA & 0 & 0 & NA & NA & NA & NA & NA & NA & NA & NA & NA \\
\hline \multirow[t]{2}{*}{ Maringá } & T. sordida & 7 & 3 & 3 & 0 & 0.0 & 4 & 1 & 25.0 & 7 & 1 & 14.3 \\
\hline & P. megistus & 22 & 14 & 11 & 1 & 9.1 & 1 & 0 & 0.0 & 12 & 1 & 8.3 \\
\hline Porto Rico & R. neglectus & 0 & 1 & 1 & 0 & 0.0 & 0 & NA & NA & 1 & 0 & 0.0 \\
\hline
\end{tabular}

${ }^{\mathrm{a}} \mathrm{NA}=$ Not applicable.

nymph) captured in each of the houses. The three species registered were $T$. sordida, P. megistus, and R. neglectus.

Out of the 96 artificial ecotopes that were infested, 65 of them were peridomestic annexes. Of these 65,51 of them (78.5\%) were located within $20 \mathrm{~m}$ of the house. Nearly all of these annexes were made of wood and were in poor condition.

As shown in Table 2, 658 specimens of triatomines were captured in all, consisting of 478 nymphs and 180 adults. The T. sordida species accounted for 575 of the specimens $(87.4 \%)$. Of these 575 specimens, 557 of them (96.9\%) were collected in either the peridomestic environment or in uninhabited houses (data not shown). P. megistus was the second most common species found, accounting for $82(12.5 \%)$ of the captured specimens, 50 of which were captured inside inhabited houses.

Table 2 also indicates that the intestinal content of 292 of the 658 triatomines $(44.4 \%)$ was examined. Of the triatomines examined, $13.4 \%(34 / 254)$ of the T. sordida and $13.5 \%(5 / 37)$ of the P. megistus were infected with T. cruzi.

Table 2 shows that Paiçandu had the highest number of captured triatomines (362/658) and also the highest levels of T. cruzi infections, $19.5 \%$ and $20.0 \%$ for T. sordida and P. megistus, re- spectively. In Mandaguari, $15.0 \%$ of the $P$. megistus triatomines were infected. T. cruzi infection was present in $14.3 \%$ and $8.3 \%$ of $T$. sordida and $P$. megistus, respectively, in Maringá. Overall, our study found that the adult specimens were more frequently infected than were the nymphs.

Of all the infected triatomines studied, only one adult specimen of $T$. sordida was found inside an inhabited house. The rest of the infected triatomines were captured in the peridomestic environment or inside an uninhabited house.

Table 3 shows the results of the tests of the triatomines' blood-meal sources, which were performed on 241 of the 658 triatomine specimens. Precipitin tests were done on a portion of the triatomines from the municipalities of Paiçandu, Dr. Camargo, and Maringá and the district of Floriano. Of the analyzed samples, 73 were nonreactive to all the tested antisera. Birds were the most frequent blood-meal source, followed by rodents, opossums, and dogs. Three triatomine specimens collected in Paiçandu municipality were positive for human blood, including one P. megistus nymph and two T. sordida adults. Of the three specimens collected in Paiçandu, only one T. sordida adult was positive for T. cruzi.

\section{DISCUSSION}

Triatomines were found in seven of the eight municipalities and also in the one district investigated in northwest Paraná; Ourizona was the one municipality that was negative. While $T$. infestans was not detected in any of the sites, specimens of T. sordida, P. megistus, and $R$. neglectus were found. Diotaiuti et al. (18) reported similar findings for artificial ecotopes in Triângulo Mineiro, Minas Gerais, Brazil.

Except for Porto Rico, all the sites were classified as either priority II or III. Triatomines were found inside inhabited houses in the municipalities of Paiçandu and Marialva even though those two sites were classified as priority III. The interior of uninhabited houses - the majority of which were built of wood and tile and thus had a propensity for the presence of rodents, wild birds, and opossums-was the ecotope category with the highest degree of triatomine infestation, particularly with $T$. sordida.

Our data confirm the findings of Toledo et al. (8) in their investigation of triatomines in northwestern Paraná. Agricultural mechanization and curtailed coffee cultivation have produced environmental changes and led to a rural exodus from northern Paraná 
TABLE 3. Blood-meal sources of triatomines captured in artificial ecotopes in northwest Paraná state, Brazil, from June 1996 to February 2000

\begin{tabular}{|c|c|c|c|c|c|c|}
\hline \multirow[b]{3}{*}{ Blood-meal source } & \multicolumn{6}{|c|}{ Location and triatomine species } \\
\hline & \multicolumn{2}{|c|}{$\begin{array}{l}\text { Paiçandu } \\
\text { Municipality }\end{array}$} & \multirow{2}{*}{$\begin{array}{l}\text { Dr. Camargo } \\
\text { municipality } \\
\text { T. sordida }\end{array}$} & \multirow{2}{*}{$\begin{array}{c}\begin{array}{c}\text { Floriano } \\
\text { district }\end{array} \\
\text { T. sordida }\end{array}$} & \multicolumn{2}{|c|}{$\begin{array}{c}\text { Maringá } \\
\text { municipality }\end{array}$} \\
\hline & T. sordida & P. megistus & & & T. sordida & P. megistus \\
\hline Bird & 70 & 0 & 18 & 18 & 1 & 5 \\
\hline Rodent & 32 & 0 & 5 & 5 & 1 & 0 \\
\hline Bird/rodent & 16 & 0 & 2 & 4 & 1 & 0 \\
\hline Opossum & 7 & 0 & 4 & 5 & 1 & 0 \\
\hline Bird/opossum & 10 & 0 & 2 & 1 & 1 & 0 \\
\hline Human/bird & 0 & 1 & 0 & 0 & 0 & 0 \\
\hline Human & 2 & 0 & 0 & 0 & 0 & 0 \\
\hline Rodent/opossum & 6 & 0 & 0 & 0 & 1 & 1 \\
\hline Cat & 2 & 0 & 0 & 0 & 0 & 0 \\
\hline Dog & 3 & 0 & 1 & 0 & 0 & 0 \\
\hline Horse & 1 & 0 & 1 & 0 & 0 & 0 \\
\hline Bird/dog & 6 & 0 & 0 & 0 & 0 & 0 \\
\hline Bird/cow & 1 & 0 & 0 & 0 & 0 & 0 \\
\hline Rodent/dog & 1 & 0 & 0 & 0 & 0 & 0 \\
\hline Cow & 1 & 0 & 0 & 0 & 0 & 0 \\
\hline Cow/horse & 1 & 0 & 0 & 0 & 0 & 0 \\
\hline Bird/dog/opossum & 1 & 0 & 0 & 0 & 0 & 0 \\
\hline Bird/rodent/opossum & 2 & 0 & 0 & 0 & 0 & 0 \\
\hline Total & 162 & 1 & 33 & 33 & 6 & 6 \\
\hline
\end{tabular}

(14), leaving in its wake many uninhabited houses that are slowly falling into ruin. Since T. sordida prefers dry tree stumps and bark and is well equipped to migrate and colonize human-modified environments $(19,20)$, it finds ideal conditions in the region to invade and colonize artificial ecotopes.

Other research $(15,21)$ indicates that $T$. sordida is frequently associated with chicken coops because of the insect's ornithophilic tendency $(19,20)$. Nevertheless, this triatomine will feed on the available food sources.

P. megistus is a species that is extremely important epidemiologically in Brazil due to its broad geographic distribution, high domestication capacity, genetic plasticity, adaptability to diverse food sources, and susceptibility to T. cruzi infection (22). The ability of $P$. megistus to colonize domiciles seems to depend on its proliferation in annexes used to shelter domestic animals (12).

One type of the annexes that we studied, sheds, have more recently replaced silos and barns in rural areas. Sheds are constructed of brick or wood and generally with a zinc roof. Used to store grain and large farm equipment, these structures are more substantial than their predecessors and are the result of agricultural mechanization. The detection of nymphs and adults of $T$. sordida and P. megistus in two sheds shows that triatomines are capable of adapting to even well-constructed structures. Furthermore, the capture of T. sordida and P. megistus nymphs illustrates the risk of triatomine colonization in artificial ecotopes that, once infected, maintain the circulation of this zoonosis in domestic and peridomestic environments.

In our study, the infection rate was $13.4 \%$ for T. sordida and $13.5 \%$ for $P$. megistus, with few specimen of the latter examined. Silveira and Vinhaes (2) reported that for all of Brazil the level of $T$. cruzi infection in triatomines in artificial ecotopes was $0.85 \%$ for T. sordida and $2.72 \%$ for P. megistus. However, infection rates in these triatomines vary greatly, depending on geographic location $(2,15,19,22-25)$. One study in Bolivia, of seven rural localities in the department of Santa
Cruz, found that $58.0 \%$ of the houses were infested with $T$. sordida and that $21.4 \%$ of the insects were infected with T. cruzi (26). In spite of this, triatomine does not pose an epidemiological risk, the authors explained. According to Noireau et al. (24), there seem to be two sympatric $T$. sordida species, Idh2 and Mdh2, in the Bolivian Chaco. Panzera et al. (27) found that there were genetic differences between a $T$. sordida population from Brazil and one from Argentina.

Our precipitin tests showed that the most common categories of bloodmeal sources for the captured triatomines were bird, rodent, bird/ rodent, opossum, and bird/opossum. $T$. sordida's preference for the blood of birds helps explain its frequency in chicken coops (28). Of all the domestic animals, dogs and, to a lesser degree, cats are the most important T. cruzi reservoirs (3). We found that as the concentration of triatomine populations increased, for example with $T$. sordida in the municipality of Paiçandu, the more eclectic its food sources became. Although competition is a causal 
factor that must be considered regarding the changes in feeding habits of the triatomines, Pires et al. (22) did not find a correlation between $T$. sordida population density and the frequency of human blood in the triatomine's digestive tract.

This article describes the results of three and a half years of studies about triatomines in the state of Paraná. The NHF is now going through a process of decentralization, and its duties are being taken over by various state-level and municipal-level entities. According to Dias (29), while the decentralization of the NHF's prevention activities in Brazil is presented as being rational both technically and operationally, discussion on this decentral- ization approach has been closed, and with scant technical input accepted. This situation has generated confusion and doubt about the transfer of responsibilities to municipalities in relation to such issues as technical training to ensure the continuity of permanent effective surveillance.

The World Health Organization held its 51st World Health Assembly in Geneva, Switzerland, in May 1998. One of the resolutions adopted there called for the interruption of Chagas' disease transmission in Latin America by the end of 2010 (30). In addition, the Southern Cone Initiative against Chagas' disease was launched in 1991 by Argentina, Bolivia, Brazil, Chile, Paraguay, and Uruguay with the aim of interrupting the transmission of Chagas' disease by eliminating domestic populations of the major vector, $T$. infestans, and by improved screening of blood donors (31).

Given all these factors, it is critical to consider the vectorial potential and adaptability of secondary triatomine species in areas where endemic disease has been controlled. We believe it is important to maintain the entomological surveillance in the rural areas of Paraná that we investigated.

Acknowledgments. Financial support for this project was provided by the Fundação Nacional de Saúde (FUNASA), agreement \#1899/98, Universidade Estadual de Maringá.

\section{REFERENCES}

1. Dias JCP. Epidemiology of Chagas disease. In: Wendel S, Brener Z, Camargo ME, Rassi A, eds. Chagas disease (American trypanosomiasis): its impact on transfusion and clinical medicine. São Paulo: ISBT Brazil; 1992. p. 49-80.

2. Silveira AC, Vinhaes M. Doença de Chagas: aspectos epidemiológicos e de controle. Rev Soc Bras Med Trop 1998;31(suppl II):15-60.

3. Barreto MP. Epidemiologia. In: Brener Z, Andrade Z, eds. Trypanosoma cruzi e doença de Chagas. Rio de Janeiro: Guanabara Koogan; 1979. p. 89-151.

4. Gazin P, Melo G, Albuquerque A, Oliveira JRW. Atualidade da doença de Chagas numa área rural do nordeste do Brasil. França-Flash Cooperação Pesquisa (CENDOTEC) 1999;(20): $1-4$.

5. Lobo AGS, Borba AM, Souza J. Contribuição ao conhecimento da distribuição geográfica dos triatomíneos domiciliários e seus índices de infecção natural pelo Schizotrypanum cruzi no estado do Paraná. Rev Bras Malariol Doenças Trop 1952;571-584.

6. Baldy JLS, Takaoka L, Pereira JD, Calixto AA, Duarte EL. Prevalência da infecção por Trypanosoma cruzi em dois bancos de sangue de Londrina, Paraná, Brasil. Rev Saúde Pública 1978;12:409-416.

7. Gomes ML, Bertolini DA, Silveira TG, Lonardoni MVC, Arraes AS. Investigação sorológica da doença de Chagas e isolamento do Trypanosoma cruzi em indivíduos de cinco municípios da região noroeste do Paraná. Rev Soc Bras Med Trop 1992;25(suppl III):94.

8. Toledo MJO, Kühl JB, Silva SV, Gasperi MV, Araújo SM. Estudo sobre triatomíneos e reservatórios silvestres de Trypanosoma cruzi no Estado do Paraná, sul do Brasil: resultados pre- liminares. Rev Soc Bras Med Trop 1997;30: 197-203.

9. Ministério da Saúde, Fundação Nacional de Saúde, Coordenação Regional do Paraná. Programa de controle da doença de Chagas: planejamento de operações de campo para o ano de 1998. Curitiba, Paraná, Brasil: Centro de Documentação do Ministério da Saúde; 1997.

10. Instituto Brasileiro de Geografia e Estatística. Geografia do Brasil. Grande região sul. Vol. 4 Tomo 1. 2nd ed. Rio de Janeiro, Brasil: IBGE; 1968.

11. Nimer E. Climatologia do Brasil. In: Instituto Brasileiro de Geografia e Estatística. Geografia do Brasil - Região sul. Rio de Janeiro: Sirgraf/IBGE; 1977. p. 35-79.

12. Instituto Agronômico do Paraná. Cartas climáticas do estado do Paraná-1994. Londrina, Paraná, Brasil: IAPAR; 1994.

13. Cigolini A, Mello L, Lopes N. Paranáquadro natural, transformações territoriais e economia. Curitiba, Paraná, Brasil: Renascer; 1998.

14. Alegre M, Moro DA. A mobilidade da população nas antigas áreas cafeeiras do norte do Paraná. Bol Geografia (UEM) 1986;4(1):28-73.

15. Diotaiuti L, Azeredo BV, Busek SCU, Fernandes AJ. Controle do Triatoma sordida no peridomicílio rural do município de Porteirinha, Minas Gerais, Brasil. Rev Panam Salud Publica 1998;3:21-25.

16. Bronfen E, Rocha FSA, Machado GBN, Perillo MM, Romanha AJ, Chiari E. Isolamento de amostras de Trypanosoma cruzi por xenodiagnóstico e hemocultura de pacientes na fase crônica da doença de Chagas. Mem Inst Oswaldo Cruz 1989;84:237-240.
17. Siqueira, AF. Estudos sobre a reação de precipitina aplicada a identificação de sangue ingerido por triatomíneos. Rev Inst Med Trop São Paulo 1960;2:41-53.

18. Diotaiuti L, Carneiro M, Loiola CCP, Silveira Neto HV, Coutinho RM, Dias JCP. Alternativas de controle do Triatoma sordida no Triângulo Mineiro. I. Borrifação parcial (intradomicílio) no município de Douradoquara, MG, Brasil. Rev Soc Bras Med Trop 1988;21: 199-203.

19. Diotaiuti L, Paula OR, Falcão PL, Dias JCP. Evaluation of the Chagas' disease vector control program in Minas Gerais, Brazil, with special reference to Triatoma sordida. Bull Pan Am Health Organ 1994;28:211-219.

20. Forattini OP, Ferreira AO, Silva EOR, Rabello EX. Aspectos ecológicos da tripanossomíase americana. XV—desenvolvimento, variação e permanência de Triatoma sordida, Panstrongylus megistus e Rhodnius neglectus em ecótopos artificiais. Rev Saúde Pública 1979;13: 220-234.

21. Soares RPP, Pires HHR, Melo MD, Pimenta PFP, Margonari C, Dujardin JP, et al. Biossistemática de Panstrongylus megistus (Burmeister, 1835). Rev Soc Bras Med Trop 1998;31 (suppl III):29-31.

22. Pires HHR, Borges EC, Andrade RE, Lorosa ES, Diotaiuti L. Peridomiciliary infestation with Triatoma sordida Stal 1859 in the county of Serra do Ramalho, Bahia, Brazil. Mem Inst Oswaldo Cruz 1999;94:147-149.

23. Diotaiuti L, Loiola CF, Falcão PL, Dias JCP. The ecology of Triatoma sordida in natural environments in two different regions of the state of Minas Gerais, Brazil. Rev Inst Med Trop São Paulo 1993;35:237-245. 
24. Noireau F, Gutierrez T, Zegarra M, Flores R, Brenière F, Cardozo L, et al. Cryptic speciation in Triatoma sordida (Hemiptera: Reduviidae) from the Bolivian Chaco. Int Med Int Health 1998;3:364-372.

25. Steindel M, Toma HK, Carvalho Pinto CJ, Grisard EC, Schlemper BR. Colonization of artificial ecotopes by Panstrongylus megistus in Santa Catarina Island, Florianópolis, Santa Catarina, Brazil. Rev Inst Med Trop São Paulo 1994;36:43-50.

26. Noireau F, Breniere F, Ordonez J, Cardozo L, Morochi W, Gutierrez T, et al. Low probability of transmission of Trypanosoma cruzi to humans by domiciliary Triatoma sordida in
Bolivia. Trans R Soc Trop Med Hyg 1997;91: 653-656.

27. Panzera F, Hornos S, Pereira J. Genetic variability and differentiation among three species of triatomine bugs (Hemiptera: Reduviidae). Amer J Trop Med Hyg 1997;57: 732-739.

28. Marsden P, Garcia-Zapata MTA, Castillo EAS, Pratas AR, Macedo VO. Los 13 primeros años del control de la enfermedad de Chagas en Mambaí, Goiás, Brasil, 1980-1992. Bol Sanit Panam 1994;116:111-117.

29. Dias JCP. Alternativas a considerar buscando a sustentabilidade das ações. Rev Soc Bras Med Trop 1999;32(suppl II):91-92.
30. Organização Mundial de Saúde (OMS). Resolução do Conselho Executivo da OMS. Rev Soc Bras Med Trop 1998;31:415-417.

31. Dias JCP, Schofield CJ. Controle da transmissão transfusional da doença de Chagas na Iniciativa do Cone Sul. Rev Soc Bras Med Trop 1998;31:373-383.

Manuscript received 28 December 2000 and accepted for publication on 18 May 2001.

RESUMEN Objectivo. Dado que existen pocos datos sobre las especies secundarias de triatominos en el estado brasileño de Paraná, este estudio investigó la infestación en casas habitadas y abandonadas y en otras instalaciones cercanas en zonas rurales de

Especies secundarias de triatominos en domicilios y otras instalaciones cercanas en municipios bajo vigilancia epidemiológica en el estado de Paraná, Brasil ese estado.

Métodos. Los triatominos fueron capturados manualmente en viviendas habitadas y deshabitadas y en otras instalaciones cercanas en nueve zonas (ocho municipios y un distrito) de Paraná entre junio de 1996 y febrero del 2000. Se realizaron pruebas para detectar la infección por Trypanosoma cruzi y pruebas de precipitación para determinar las fuentes alimentarias de los triatominos.

Resultados. Aunque no se detectó Triatoma infestans en ninguna de la nueve zonas estudiadas, se detectaron tres especies secundarias de triatominos: Triatoma sordida, Panstrongylus megistus y Rhodnius neglectus. La más frecuente fue T. sordida, a la que pertenecían 575 de los 658 triatominos capturados $(87,4 \%)$. La segunda más frecuente fue $P$. megistus, con 82 especímenes (12,5\%). De los varios tipos de instalaciones investigadas, las casas deshabitadas fueron las más frecuentemente infestadas (19/62; $30,6 \%)$, seguidas de los gallineros $(24 / 350 ; 6,9 \%)$. La fuente alimentaria primaria de los triatominos fue la sangre de las aves. No obstante, en el municipio con mayor densidad de triatominos, las fuentes alimentarias incluían los animales domésticos e incluso los seres humanos. Se comprobó que el 13,4\% de los especímenes de T. sordida y el $13,4 \%$ de los especímenes de $P$. megistus estaban infectados por T. cruzi.

Conclusiones. Estos resultados demuestran la necesidad de mantener medidas de vigilancia entomológica en las zonas estudiadas. Esto es especialmente importante, dado que Brasil y otros países de América Latina han manifestado la necesidad de interrumpir la transmisión vectorial de la enfermedad de Chagas. 